\title{
PERCEPTION OF HEALTH PROFESSIONALS ABOUT THE PREVENTION OF THE AIDS EPIDEMIC IN FLORIANÓPOLIS, SANTA CATARINA, BRAZIL (1986-2006)
}

\author{
Mariana Vieira Villarinho', Maria Itayra Padilha², Isabel Cristina Alves Maliska ${ }^{3}$, Maria Ligia dos Reis \\ Bellaguarda ${ }^{4}$, Camila Sell ${ }^{5}$, Aline Coelho Ferreira ${ }^{6}$
}

\footnotetext{
${ }^{1}$ Ph.D. in Nursing.Occupational Nurse in the State Department of Administration of Santa Catarina. Florianópolis, Santa Catarina, Brazil. E-mail: nanyufsc2004@gmail.com

2 Ph.D. in Nursing.Professor at the Department of Nursing, Universidade Federal de Santa Catarina (UFSC). CNPq Researcher. Florianópolis, Santa Catarina, Brazil. E-mail: padilha@nfr.ufsc.br

${ }^{3}$ Ph.D. in Nursing.Registered Nurse at the UFSC's University Hospital. Florianópolis, Santa Catarina, Brazil. E-mail: isabel. alves@yahoo.com.br

${ }^{4}$ Ph.D. in Nursing. Professor in Faculty of Nursing at Centro Universitário Estácio de Sá. São José, Santa Catarina, Brazil. E-mail: bellaguardaml@gmail.com

${ }^{5}$ Master in Nursing by the Graduate Program in Nursing at UFSC. Registered Nurse. Florianópolis, Santa Catarina, Brazil. Email: camillasell@hotmail.com

${ }^{6}$ Master's student in the Graduate Program in Nursing at UFSC. Registered Nurse at the SOS Cardio Hospital. Florianópolis, Santa Catarina, Brazil. E-mail: alini_zinhaa@hotmail.com
}

\begin{abstract}
Socio-historical research whose aim was to know the perception of health professionals about AIDS epidemic prevention from 1986 to 2006. They worked in a reference hospital for infectious and contagious diseases. The data was collected from March to October 2011, using the oral story technique, and the subjects were twenty-three health professionals who looked after people suffering from Acquired Immune Deficiency Syndrome during the above mentioned period. The content analysis described by Bardin was used and two categories came up: the need for preventive strategies and the lack of using condoms. The results showed that the health professionals' perception about AIDS prevention was bad due to: the media fragility, the health professionals' actions regarding preventive strategies and the trivialization of the preventive measures by the society, by not using condoms in sexual intercourse. We concluded that ignoring the disease led to slowing down the process of clarifying and preventing HIV/AIDS.
\end{abstract}

DESCRIPTORS: Acquired Immunodeficiency Syndrome. Health personnel History.

\section{PERCEPÇÃO DOS TRABALHADORES DA SAÚDE ACERCA DA PREVENÇÃO DA EPIDEMIA DA AIDS EM FLORIANÓPOLIS-SC, BRASIL (1986-2006)}

RESUMO: Pesquisa sociohistórica que objetivou conhecer a percepção dos trabalhadores da saúde de um hospital referência em doenças infectocontagiosas acerca da prevenção da epidemia da aids, 1986 a 2006. Os dados foram coletados de março a outubro de 2011, utilizando a técnica da história oral, com vinte e três trabalhadores da saúde que cuidaram de pessoas com aids, no período do estudo. Utilizou-se a análise de conteúdo de Bardin, na qual emergiram duas categorias: necessidade de estratégias de prevençãoe não uso do preservativo. Os resultados mostram que a percepção dos trabalhadores da saúde acerca da prevenção da aids ao longo da epidemia foi ruim, relacionado as fragilidades da mídia, dos profissionais da saúde nas ações de prevenção e a banalização da prevenção pela própria sociedade, ao não usar o preservativo nas relações sexuais. Concluímos que desconhecer a doença resultou na lentidão de esclarecimentos e prevenção acerca do HIV/aids.

DESCRITORES: Síndrome da Imunodeficiência Adquirida. Pessoal de saúde. História.

\section{PERCEPCIÓN DE LOS PROFESIONALES DE SALUD ACERCA DE LA PREVENCIÓN DE LA EPIDEMIA DEL SIDA, EN FLORIANÓPOLIS-SC, BRASIL (1986-2006)}

RESUMEN: Investigación socio-histórica cuyo objetivo fue conocer la percepción de los profesionales de salud de un hospital referencia en enfermedades infecto-contagiosas acerca de la prevención de la epidemia del SIDA de 1986 hasta 2006. Los datos fueron recopilados de marzo a octubre de 2011, utilizando la técnica de historia oral, con veintitrés profesionales de la salud que estuvieron a cargo del cuidado de personas con el síndrome de inmunodeficiencia adquirida durante el período del estudio. Fue utilizado el análisis de contenido descrito por Bardin, del cual surgieron dos categorías: necesidad de estrategias de prevención y falta de uso de preservativos (condones). Los resultados muestran que la percepción de los profesionales de la salud sobre la prevención del SIDA a lo largo de la epidemia fue mala, lo que está relacionado a las fragilidades de los medios de comunicación, a los profesionales de la salud en las acciones de prevención y a la banalización de la prevención por la misma sociedad, al no usar condones en las relaciones sexuales. Concluimos que desconocer la enfermedad tuvo como resultado la lentitud en las aclaraciones y prevención sobre el HIV/SIDA.

DESCRIPTORES: Síndrome de Inmunodeficiencia Adquirida. Personal de salud. Historia. 


\section{INTRODUCTION}

HIV/AIDS is considered a significant social phenomenon in the relationships between people, since it covers aspects related to ethics, religion, sexuality, drugs and even conjugal morality. ${ }^{1}$ Starting with the development of public policies and financing, technological advances and research, a relentless pursuit for knowledge about the HIV began, as well as for prevention strategies to avoid and/or minimize the epidemic process.

In Brazil, in the early 80s, while HIV/AIDS was destroying many lives, an interaction between society and public policies was established. When the Ministry of Health established the National AIDS Program (NP-STD/AIDS) in 1986, one of its first directives for combating the epidemic was the recognition of AIDS as a public health problem. ${ }^{2}$

In this context, the state of Santa Catarina (SC), as well as theentire national territory, joined this activism, in the search for solutions to the epidemic process of HIV / AIDS. The first case of AIDS was reported in the state in 1984, and in the capital, Florianópolis, in 1986. With the occurrence of the first cases of AIDS, the Hospital Nereu Ramos (HNR), a center of excellence in communicable diseases in SC, scenario of this study, located in Florianópolis, began to structure itself reserving hospital beds and creating an outpatient clinic for following up cases of the disease that were multiplying. Besides thephysical infrastructure, healthcare professionals of the institution began preparing themselves to assist both hospitalized patients, with complications, and to receive suspect cases, families and the population that sought information about the epidemic. ${ }^{3}$

When referring to the history of the AIDS epidemic, it is possible to observe that its development happened in many different ways in relation to the epidemiological patterns, the psychosocial effects, the treatment and particularly in relation to the aspects related to HIV prevention. This is how we seek to present, in this manuscript, a part of the history related to the evolution of AIDS, which health workers experienced in caring for people with this syndrome hospitalized in the HNR, especially with regard to perceptions of professionals in relation to AIDS prevention during the epidemic.

In this sense, the objective established for this study was to learn the perception of health workers from a hospital,which is a center of excellence in communicable diseases, regarding the prevention of the AIDS epidemic, from 1986 to 2006.

The option to (re)construct the history of this period, 1986 to 2006, is due to the first reported case of AIDS in Florianópolis, city where the HNR is located, scenario of this study, with the final year 2006 being justified by the closing of the Florianópolis STD/AIDS outpatient clinic, due to the decentralization of AIDS services in the municipality. The desire to perform a research with healthcare workers, guided by their stories and memories, is due to the understanding about how much these memories and experiences, about their care practices with patients with HIV / AIDS throughout the epidemic, reveal their perceptions about prevention, and what they needed to do in relation to developing actions and awareness strategies aiming at preventing and minimizing the transmissibility of HIV.

\section{METHODOLOGY}

Socio-historical research with a qualitative approach, in which the oral history $(\mathrm{OH})$ technique was used as a method of source for data collection. This type of research consists in a systematic collection of data that are related to past events, with the aim to shed light on the past so that it can clarify the present, also enabling the perception of future issues. ${ }^{4}$ The useof the $\mathrm{OH}$ for data collection was chosen because this technique enables the conduction of interviews with people who witnessed, testified and/or participated in events in a given social context. ${ }^{4}$

Data were collected from March to October of 2011 by means of semi-structured interviews with 23 health workers who provided care to people with HIV/AIDS admitted to HNR, from 1986 to 2006, including four physicians, eight nurses, four nursing technicians, three nursing aides, a dentist, a nutritionist, a social worker and a psychologist. Inclusion criteria were: health workers who worked in the care of patients with HIV / AIDS during the study period (1986 to 2006); who possessed good memory about the development of their labor practices with the patients mentioned; and who had availability and interest in participating in the research.

The selection of individuals to participate in the research was initiated with a request made to the Human Resources of the HNR and a recommendation made by the workers who had already been interviewed. All interviews were scheduled in advance, in accordance with the subjects' availability, respecting the place, date and time suggested by them. Besides the hospital, some interviews took place in the homes of the subjects, and others in their current workplace. 
After the process of data collection, data were transcribed in order to preserve the reliability of the statements. In this stage, we tried to identify structures of relevance and to make a regrouping by themes, according to Bardin's content analysis, ${ }^{5}$ in which the following categories emerged: the need for prevention strategies and the non-use of condoms. These categories addressed the perception of healthcare workers about the prevention of AIDS throughout the epidemic.

In accordance to the Resolution 196/96 of the National Health Council, the research that led to this manuscript was submitted to the Human Research Ethics Committee (CEPSH, as per its acronym in Portuguese) of the Federal University of Santa Catarina, being approved with the process number 920/10. All subjects who agreed to participate signed a Free and Informed Consent Form (FICF). ${ }^{6}$ Considering that some study subjects refused to be identified by their name, it was decided to guarantee anonymity to all, and the subjects were presented with letters relating to their occupational categories and with numbers, in order to follow the chronological order in which they worked at HNR (for example, medical doctor M1, registered nurse E3, nursing technician TE2, nursing aide AE1, dentist D1, social worker AS1).

\section{RESULTS AND DISCUSSION}

The results of this research are presented in two discursive groups, allowing the reader to envision the course of data analysis, seeking to understand the perception of healthcare workers about the prevention of the AIDS epidemic during the study period.

\section{The need for prevention strategies throughout the epidemic period}

In this category, the health workers mentioned the importance and the need to adopt preventive strategies to decrease transmission of HIV, especially geared to Injection Drug Users (IDUs), homosexuals, prostitutes, since these are considered risk groups in the beginning of the epidemic. However, unfortunately, throughout the history of AIDS, prevention efforts have apparently been forgotten by the media, by the health professionals, as shown by the testimony:

[...] it was necessary to work with the prevention, because the epidemic grew frighteningly. AIDS was growing strong, many cases were arising, especially with young homosexuals, injection drug users... and because we are a center of excellence in the state, in the training we always worked with prevention. It was an absurd to talk about AIDS without talking about prevention [...] (M1).

[...] prevention was fairly worked by nurses. At the beginning, the main focus was on prevention for drug users, homosexuals, but after a while they began to raise awareness, to conduct prevention activities also to married women, young people... because there was no risk group anymore and safer sex had to be built on everyone's mind [...] (D1).

[...] when the history about AIDS began, there was a lot of talk, much publicity, even the Ministry of Health itself under pressure from the media, was doing more prevention campaigns. And we invested in prevention in a frequent manner and not just on specific dates [...] (E3).

The reports demonstrate the concern of health workers from the HNR regarding the measures for preventing the transmission of HIV among the population throughout the epidemic, during the study period, and in the beginning, these preventive actions were done mainly for the "risk groups" and later they were extended to other population groups, understanding that the epidemic was not confined only to certain social groups, but to behaviors that determined a higher risk and therefore higher vulnerability to HIV transmission.

Within the scope of the disease, which is understood as a dynamic and multicausal process, the notions of risk and vulnerability assume a contextualized view about the illness process, constituting circumstances and probabilities of occurrence of a certain damage. ${ }^{7}$ Risk and vulnerability, despite having a close relation, are distinct, and perhaps the greatest contribution to the debate on the distinction of both terms is in the effort to shift the notion of individual risk to a perception of social vulnerability. ${ }^{8}$

The notion of risk behavior was a major breakthrough to the extent that it led to solidarity of socially excluded groups, recognition of society as vulnerable to infection and to the search for preventive behaviors rather than prescriptive ones. The notion of vulnerability withdrew the prevention from the individual level only and placed it with the political, economic, social and cultural complexity, where people are found. ${ }^{7}$

With further reflection on the occurrence of risk situations and behaviors, studies confirmed that these are under a situation of broader vulnerability, determined not only by individual actions. ${ }^{7-8}$ Our society seeks to label the standards of ideal human behavior, not only with respect to sexual ori- 
entation, where everyone should be heterosexual; but also on the way of practicing such option, particularly valuing stable and lasting relationships. ${ }^{9}$

In the perspective of this study and according to the perceptions of the health professionals about prevention of HIV/ AIDS at the beginning of its rise, the need to disseminate actions of health education among the population was felt. However, the exceptionality of the epidemic was being gradually attenuated to the point that these actions were being neglected by the government, militants, even by health workers, who besides assisting and caring, had a commitment and a responsibility to educate and prevent. This fact deserves attention, because from the moment that the category of sexual transmission came to be considered the main way of transmitting $\mathrm{HIV}$, the profile of the epidemic changed, and in that perspective it was correct and necessary to invest in planned and continuous prevention strategies that could reach all people, regardless of their sexual orientation.Given that, in relation to AIDS, everyone is vulnerable, the notion about risk groups becomes obsolete, and what really determines the chance of infection to occur are the behaviors, attitudes and the lack of prevention strategies against the epidemic. ${ }^{10}$

In this sense, the health professional had to commit to investing broadly in preventive actions to everyone, given that the attribution of characteristics such as promiscuous or "not normal" to individuals were the major misconceptions that health workers, concerned with AIDS prevention, should avoid.

\section{The non-use of condoms}

In this category, the perception of healthcare workers about the prevention of AIDS, throughout the epidemic, was in the aggravating conduct of some people who chose not to use condoms during sexual intercourse. According to statements, such trivialization about condom use was associated with the chronic nature of AIDS, starting with the antiretroviral treatment (ARV), which in turn increased the survival of the person with the virus, and with the fact that some individuals had not experienced the stigma and discrimination in relation to the AIDS in the rise of the epidemic. Moreover, from the viewpoint of health workers, the non-use of condoms by the population was also associated with the culture of male chauvinism, with the feelings of invulnerability, as well as with the fact that sex is linked to pleasure, pas- sion, physical attraction, involving feelings that reverberated in unsafe sex.

People began not to take care of themselves, not using condoms, health professionals began not to adhere to protective measures during care. At first, there was great fear and after with the treatment, with the characterization of AIDS as a chronic disease, people started to get used, relaxing, trivializing HIV transmission (E1).

The fact that AIDS became a treatable illness, and was considered a chronic disease, caused people to minimize their preventive care [...] (E4).

With regard to the non-use of condoms associated with the chronic nature of AIDS, in consequence to the access to antiretroviral therapy in the mid-90s, and with the law 9.313 of January 13, 1996, which assured treatment for free for all people affected by HIV/AIDS, the history of the syndrome changed..$^{11}$ Despite AIDS being an incurable disease, scientific advances related to the proposed therapy "High Active Antiretroviral Therapy" (HAART) configured a great achievement, since it conferred significant benefits in improving the life expectancy of HIV positive people. ${ }^{12}$

Regarding the achievement of access to treatment for people with AIDS, the Brazilian response, in the field of care and treatment to the epidemic, was structured during an earlier period, already in 1986, with the creation of the STD/AIDS Programin the state and national scope, focused on the prevention and financing of health services for diagnosis and treatment, at that time, with the distribution of zidovudine (AZT), the only drug available, starting in 1987. ${ }^{13-14}$

[...] with the treatment for AIDS, people began to live better, they might even die of old age, but not from AIDS, and I see that this is why people were uncommitted with their care, having sexual intercourse with anyone and not using condoms anymore [...] (M2).

The indifference of people in relation to the use of condoms during sexual intercourse due to drug developments and the availability of high power antiretroviral therapy free of charge to people affected by the disease caused noticeable impact on the reality of the epidemic, since it reduced morbidity and mortality and the number of hospitalizations and increased the survival of patients who now live longer and better. There is no doubt that the policy of universal access to treatment increased the survival and improved the quality of life of people living with HIV, establishing a profile of chronicity to AIDS. ${ }^{15}$ However, it is necessary to reflect, because if on one hand the treatment brought improvement in the survival 
of people with the virus, on the other, the chronicity of the disease reflected in the trivialization of the population in preventing AIDS, not using condoms during sexual intercourse.

This situation of trivialization, showed by the non-use of condoms during sexual intercourse, and which deserved special attention, according to the reports of health workers who provided care to patients with HIV / AIDS, were also serodiscordant couples. In the national and international literature the term serodiscordant is broadly used to describe heterosexual or homosexual couples in which one partner is HIV positive and the other is not. ${ }^{16}$

[...] the treatment came with more potent drugs to provide better quality to patients, but I see that with it [treatment] there was an oversimplification of the disease, particularly among serodiscordant couples [...] (E7).

[...] people did not use condoms, including serodiscordant couples. When I assisted these couples, the person who had the virus used to say: 'what can I do? If I get it, there is medication' (M4).

With the chronicity of AIDS, the reality of those who lived with the disease was gradually being changed, creating new challenges for their understanding and coping, including by health professionals who provided treatment to peoplewho were HIV positive and their partners who were HIV negative. One of the questions raised by this reality concerns the actions of health professionals in interrupting the chain of transmission of $\mathrm{HIV}$, working specifically on prevention strategies, jointly with the services and health policies.

In regard to serodiscordant couples, there are unique factors that distinguish and justify a differentiated assistance, which requires greater visibility among the health professionals, and calls attention for better understanding, given the range of challenges related to the maintenance of emotional-sexual life and the coping of the sexual prevention of HIV. ${ }^{16}$ Despite major advances achieved regarding the diagnosis and treatment of HIV/ AIDS, its prevention imposes constant challenges and demands effective and permanent educational activities in order to avoid and/or minimize the vulnerability of individuals with HIV/AIDS infection.

Also with respect to the failure to use condoms during sexual intercourse, health workers made the presence of such risk behavior among young people quite evident in their statements.

People, especially young people, did not take care of themselves, did not care about condoms. We could see this through these girls who became pregnant all the time. Beloved Jesus, apart from AIDS there were also the STDs [...] (AE2).

With the opportunity of treatment and survival of patients with HIV, young people were careless, not using condoms. I think because they had not experienced the onset of AIDS and had no dimension of the losses with the deaths due to lack of treatment, all that discrimination [...] (E2).

The statements remarkably showwhat AIDS, for being a new and devastating disease in which the real form of transmission was unknown, caused to the population at that time, such as rejection, stigma and fear. Nevertheless, being initially linked to homosexuality and promiscuity, the perception of the society, including health workers and HIV positive people and their families, with respect to the disease often presented discrimination, prejudice and stigma. Such attitudes constituted a challenging aspect for people with the disease who had to experience different confrontations after facing the diagnosis. ${ }^{17}$

The omission of the diagnosis is often extended to the families, because of fear about how the family will react and face the new situation, but also because of fear of rejection and discrimination by their relatives. Thus, the constant need for hiding the infection diagnosis from society is remarkable in the lives of people with HIV/AIDS. ${ }^{18}$

In face of such situation experienced at that time, an incessant search for knowledge about AIDS and the demystification of the disease to the population was became necessary. ${ }^{19}$ Consequently, the stigmatized way people with HIV / AIDS were labeled during the epidemic was drastically minimized, although this is still not fully resolved. ${ }^{20} \mathrm{In}$ contrast, the lack of fear of the disease and somehow its very demystification might have passed on to the exacerbation of confidence and sense of invulnerability by the young, causing the trivialization of AIDS. Therefore, despite the implementation of public health policies, mainly aimed at the prevention of STDs among the youth audience, they mostly did not experience the drama at the beginning of the epidemic, the stigma for those infected and the experience of prejudice directed at people with the disease.

Regarding the feeling of invulnerability, such subcategory was also identified by health workers as being crucial not to use condoms, as evidenced by thesestatements:

[...] at the beginning, prevention was focused on injection drug users, prostitutes, homosexuals, with the strong work of prevention, they began to care for them- 
selves, protect themselves, and our patients changed. A different group of people, especially married women, began being admitted to Nereus [...] (M1).

[...] AIDS was strong among young and olderindividuals and married women... because people felt invulnerable. So it was difficult to make people understand the importance of using condoms in any sexual intercourse, even with a regular partner [...] (TE2).

[...] the deal was to work with people's minds, and nursing did it very well, raising awareness about the importance of using condom, working the sexist conception of man to use a condom, and of women to demand the use from their partner [...] (N1).

The statements show that homosexuals and IDUs started, after this awareness work, to adopt preventive measures more frequently than other population groups, such as the use of condoms during sex and not sharing contaminated needles. On the other hand, heterosexuals, who considered themselves invulnerable to HIV transmission, ended up exposing themselves to risk conducts and behaviors.

Condom use adherence among homosexuals was given to the fact that gay sexuality is, unlike heterosexual sexuality, less tied to the rigidity of male and female roles, culturally defined in gender relations, which made them more receptive and able to adopt safer sexual practices. In contrast, heterosexuals hada representation of immunity to infection, and thus maintained their same codes of sexual behavior, which involved vaginal sex as the prevalent practice, in which each woman negotiated safer sex, from their position of greater or lesser power. ${ }^{21}$

Unfortunately, the culture of male chauvinism, the subordination of women in gender relations, arising from the symbolic constructions of masculinity and femininity, the sense of invulnerability to HIV transmission, as well as the fidelity expected in relationships, made women not demand, from their regular partners, condom use. ${ }^{21}$ These situations influenced in changes in the epidemiological profile, since there was an increase in the number of cases of HIV transmission among heterosexuals, especially among married women.

The alarming increase of AIDS, as well as the significant change in the epidemiological profile, with the heterosexualization of the disease, from the point of view of the health workers, participants in this present study, happened in consequence to the fact that the main way of HIV transmission is sexual, which is linked with pleasure, passion and physical attraction, as evidenced by the statements:
[...] the AIDS epidemic went out of control because it is transmitted through sex, which is part of being human. So people let themselves be carried away, be controlled, and involved by the relationship, by the sexual involvement, they end up not using condoms [...] (M2).

[...] it is difficult to control an epidemic, where most transmissions occur by unprotected sex and rather than by lack of knowledge, information [...] (E8).

[...] if the HIV was only transmitted by blood transfusion or professionally, we could control this epidemic. But when it involves relationship, sex is difficult to control, even with good guidance on condom use [...] (E3).

Sex is the dominant category of HIV transmission in Brazil, especially among women. It is noteworthy, based on the data presented by the Epidemiological Bulletin of the Ministry of Health, ${ }^{22}$ that the HIV infection has shown changes in the profile of people infected. In the first decades of the epidemic, from 1980 to 1997, $45.5 \%$ of AIDS cases were among IDUs, $17.1 \%$ among homosexuals, 9.7\% among bisexuals, and $11.9 \%$ among heterosexuals. Over the years, the data confirm this changing profile, considering that in 2011, exposure category among men was distributed in heterosexual $(26.7 \%)$, followed by homosexual $(36.9 \%)$, bisexual (11.4\%) and IDUs (5.5\%). Among women, in this same year, 2011, the main category of exposure was heterosexual $(81.1 \%)$, followed by IDUs $(3.8 \%) .{ }^{22}$

In Santa Catarina, the epidemiological reality about AIDS is not different. The main exposure category in the state is heterosexual $(61.9 \%)$, followed by IDUs (20.9\%) and homosexual (9.1\%). The first case among women occurred in 1987 and, since then, the number of cases among women is growing, and the masculinity ratio has been decreasing every year, from the ratio of 4.8 in 1987 to 1.6 in the year of 2011. These data shows the heterosexualization of AIDS and also highlight the feminization of the epidemic in Brazil and in the state of Santa Catarina. ${ }^{23}$ In this perspective, the trend of heterosexualization of AIDS occurs primarily with sex, a moment in which positive emotions are much more present, making it difficult to link physical attraction and passion to the idea of sickness and death. ${ }^{24}$

Sex, especially when imbued with feelings of love and passion, has components that keepthe risk away. This component arises from the construction of a sense of invulnerability, typical of people in love, who feel absolute, powerful. ${ }^{25}$

Given this scenario, preventive actions related to AIDS are a major challenge to health 
professionals, since there is the need to deal not only with information, but with beliefs, feelings and cultural values that influence the social and sexual behavior of people, reflecting in potential vulnerability to the epidemic, that despite suffering transformations over time, remains a problem of public health concern until today.

\section{FINAL CONSIDERATIONS}

The development of this study showed that HIV / AIDS involves a process of orientation, politicization, and clarification, both for health professionals and for the affected and general population. Health professionals, as unique beings who also have attitudes, values and differentiated experiences, tried to indicate, guide and provide health care, within the reality presented and according to the epidemiological reality of the time. The perceptions of health professionals revealed several contradictions, taking into consideration that those circumstances were new and unfamiliar to them. Therefore, the whole process of enlightenment and learning about prevention of this disease was slow.

This study also highlighted the educational and health initiatives developed by professionals who experienced the development of the AIDS epidemic in their working process. Their perceptions are the product of the experience gained over the years, andportray the development of the epidemic, highlighting, in particular, the availability of antiretroviral drugs, and the change in the perspective of AIDS from a lethal to a chronic disease. This new reality, admittedly positive, reflected in the trivialization of the epidemic felt by these professionals, especially for younger populations that have not experienced the tragedy of AIDS in its rise, bringing consequences for the prevention (dis)practices.

Finally, the movement of prevention related to HIV/AIDS presented in the perspective of this study refers to the precaution, the practice of safer sex and adherence to drug therapy, challenges which extend both to individuals affected by the disease and to the health services that support them. The limitations in conducting the study correspond to the ones of all investigative processes, the issues of time and number of participants. However, the research presents the contribution that, from the story, told and written, it was possible to document the strengths and weaknesses of health care. In this sense, the experience presented here can also support health professionals in the development of educational strategies and effective care practices to promote healthy habits to prevent HIV/AIDS.Nevertheless, it is important to note that the successful development of prevention strategies depends on the collaboration and co-participation of professionals and health service users and managers, as well as the public government.

\section{REFERENCES}

1. Oliveira DC, Oliveira EG, Gomes AMT, Teotônio MC, Wolter RMCP. O Significado do HIV/aids no processo de envelhecimento. Rev Enferm UERJ. 2011 Jul-Set; 19(3):353-8.

2. Souza BMB, Vasconcelos CC, Tenório DM, Lucena MGA, Holanda RLT. A política de aids no Brasil: uma abordagem histórica. J Manag Prim Health Care. 2010; 1(1):23-6.

3. Maliska ICA. A implantação das políticas públicas de saúde em aids no município de FlorianópolisSC: um estudo do período de 1986 a 2010 [Tese]. Florianópolis (SC): Programa de Pós-Graduação em Enfermagem Universidade Federal de Santa Catarina; 2012.

4. Padilha MS, Borenstein MS. O método de pesquisa histórica na enfermagem. Texto Contexto Enferm. 2005 Out-Dez; 14(4):575-84.

5. Bardin L. Análise de conteúdo. Lisboa (PT): Edições 70; 2004.

6. Ministério da Saúde (BR). Conselho Nacional de Saúde, Comissão Nacional de Ética em Pesquisa. Resolução n. 196 de 10 de outubro de 1996: diretrizes e normas regulamentadoras de pesquisa envolvendo seres humanos. Brasília (DF): MS; 1996.

7. Girondi JBR, Backes MTS, Argenta MI, Meirelles BHS, Santos SMA. Risco, vulnerabilidade e incapacidade: reflexões com um grupo de enfermeiras. Rev Eletr Enferm [online]. 2010 [acesso 2012 Abr 18]; 12(1):207. Disponível em: http:/ / www.fen.ufg.br/revista/ v12/n1/pdf/v12n1a03.pdf

8. Buchalla CM, Paiva V. Da compreensão da vulnerabilidade social ao enfoque multidisciplinar. Rev Saúde Pública. 2002 Ago; 36(4):117-9.

9. Camargo BV, Giacomozzi AI, Wachelke JFR, Aguiar A. Relações amorosas, comportamento sexual e vulnerabilidade de adolescentes afrodescendentes e brancos em relação ao HIV/aids. Saúde Soc. 2010 Dez; 19(supl 2):36-50.

10. Villarinho MV. Evolução das práticas de cuidado dos trabalhadores da saúde às pessoas com HIV/ aids, em um hospital referência em doenças infecto contagiosas de Santa Catarina: no período de 1986 a 2006 [tese]. Florianópolis (SC): Programa de PósGraduação em Enfermagem Universidade Federal de Santa Catarina; 2012. 
11. Ministério da Saúde (BR). Lei n. 9.313, de 13 de novembro de 1996: dispõe sobre a distribuição gratuita de medicamentos aos portadores do HIV e doentes de AIDS. Brasília (DF): MS; 1996.

12. Geocze L, Mucci AS, Marco MA, Nogueira-Martins LA, Citero VA. Qualidade de vida e adesão ao tratamento anti-retroviral de pacientes portadores de HIV. Rev Saúde Pública. 2010 Ago; 44(4):743-9.

13. Ministério da Saúde [página na Internet]. Aids vinte anos: esboço histórico para entender o Programa brasileiro. História do Programa Nacional. Brasília (DF): MS; 2006 [atualizado 2012 Mar 04; acesso 2012 Abr 18]. Disponível em: http:/ / www2.aids.gov.br/ data/Pages/LUMISBD1B398DPTBRIE.htm

14. Villarinho MV, Padilha MI, Berartinelli LM, Borenstein MS, Meirelles BH, Andrade SR. Políticas públicas de saúde face a epidemia da aids e a assistencia às pessoas com a doença. Rev Bras Enferm. 2013 Mar-Abr; 66(2):271-7.

15. Schaurich D, Coelho DF, Motta MGC. A cronicidade no processo saúde-doença: repensando a epidemia da aids após os anti-retrovirais. Rev Enferm UERJ. 2006 Jul-Set; 14(3):455-62.

16. Reis RK, Gir E. Convivendo com a diferença: o impacto da sorodiscordância na vida afetivo-sexual de portadores do HIV/aids. Rev Esc Enferm USP. 2010 Set; 44(3):759-65.

17. Maliska ICA, Padilha MIC, Vieira M, Bastiani J. Percepções e significados do diagnóstico e convívio com o HIV/aids. Rev Gaucha Enferm. 2009 Mar; 30(1):85-91.

18. Vieira M, Padilha MIC, Santos EKA. Histórias de vida - mãe e filho soropositivo para o HIV. Texto Contexto Enferm. 2009 Jan-Mar; 18(1):33-40.
19. Oliveira DC, Costa TL, Gomes AMT, Acioli S, Formozo GA, Heringer A, et al. Análise da produção de conhecimento sobre o HIV/aids em resumos de artigos em periódicos brasileiros de enfermagem, no período de 1980 a 2005. Texto Contexto Enferm. 2006 Out-Dez; 15(4):654-62.

20. Monteiro S, Villela WV, Knauth D. Discrimination, stigma, and AIDS: a review of academic literature produced in Brazil (2005-2010). Cad Saúde Pública. 2012 Jan; 28(1):170-6.

21. Rodrigues LSA, Paiva MS, Oliveira JF, Nobrega SM. Vulnerabilidade de mulheres em união heterossexual estável à infecção pelo HIV/aids: estudo de representações sociais. Rev Esc Enferm USP. 2012 Abr; 46(2):349-55.

22. Ministério da Saúde [página na Internet]. Boletim Epidemiológico AIDS/DST, ano IX, n. 01, até semana epidemiológica $26^{\circ}$ - junho de 2012. Brasília (DF): MS; 2012 [atualizado 2012 Jun 24; acesso 2012 Ago 28]. Disponível em: http://www.aids.gov.br/sites/ default/files/anexos/publicacao/2012/52654/ boletim_jornalistas_pdf_22172.pdf

23. Secretaria de Estado da Saúde, Diretoria de Vigilância Epidemiológica, Gerência de Vigilância das DST/HIV/AIDS. 27 anos da epidemia de aids: Uma história de lutas, desafios e avanços. Florianópolis (SC): SES; 2011.

24. Seffner F. Com vírus, sem vírus: afeto, amor, amizade, vida sexual e aids. In: Padoin SMM, Paula CC, Shaurich D. Aids: o que ainda há para ser dito? Santa Maria (RS): ed. UFSM; 2007. p. 29-45.

25. Paiva V. Sem mágicas soluções: a prevenção e o cuidado em HIV/AIDS e o processo de emancipação psicossocial. Interface Comunic Saúde Educ. 2002 Ago; 6(11):25-38 